\title{
The Common Law Baseline and Restitution for the Lost Commons: A Reply to Professor Epstein
}

\author{
Frank Michelman $\dagger$
}

\section{DEFINING "PROPERTY" IN TAKINGS ADJUDICATION}

The Constitution's Takings Clause requires governments in this country to pay for any property they take from private owners. ${ }^{1}$ The bounds of this requirement's coverage are disputed, within limits. Most agree that coverage extends beyond cases of express, formal appropriation and of total physical takeover by the government. No one, however, says it reaches every single instance of governmental incursion or restriction on private owners' preexisting deployments and enjoyments of what they own. Whether payment is constitutionally required for this or that partial incursion or restriction is always, therefore, a question for decision by responsible officers-judges, in the last resort. Decision requires a method for deriving the antecedent scope and content of a constitutionally safeguarded "property" interest, because if the governmentally discommoded deployment or enjoyment is not within that scope, then, in a constitutional sense, no "property" is taken.

According to a so-called positivist view, a property holding's scope is always necessarily hostage to state lawmaking. "Property," in this view, consists of nothing but the law's confirmation of entitlements and prerogatives to possessors or other "owners." Property's content, therefore, can be nothing but the sum of whatever such confirmations a state's laws from time to time see fit to include. ${ }^{2}$ For example, if the laws deny landowners

$\dagger$ Robert Walmsley University Professor, Harvard University. This Article was commissioned for and presented at an American Enterprise Institute conference on legal and economic perspectives on takings held in March 1996.

' See US Const, Amend V ("[N]or shall private property be taken for public use, without just compensation."); US Const, Amend XIV, $\$ 1$ ("[N]or shall any State deprive any person of life, liberty, or property, without due process of law."); Lucas $v$ South Carolina Coastal Council, 505 US 1003, 1028 n 15 (1992) (confirming "incorporation" of Fifth Amendment Takings Clause in Fourteenth Amendment Due Process Clause).

' See, for example, Jeremy Bentham, The Theory of Legislation 111-13 (Rothman reprint 1987 of C.K. Ogden ed 1931): 
the freedom to build houses at the seashore, then, by the same token, "property" does not encompass this freedom. Can such an accordion-like conception of property possibly serve as the baseline for constitutional "taking" determinations? If it did, then arguably there could be no such constitutionally cognizable event as a "regulatory taking;" " the compensation mandate would be confined to cases of (1) legally unauthorized incursions by misbehaving government agents, and (2) formal expropriations from private to government ownership. Such a result strikes Professor Epstein and many others as plainly out of whack with the design of the Takings Clause to serve as a shield against majoritarian abuse. In order, they say, to honor this power-limiting design, we have to read into the clause some already fixed conception of the core content of an "ownership" or "property" entitlement. This conception must be one that can withstand on-going modifications of state law by majoritarian organs of government, because only such a securely trans-majoritarian property baseline can ground a contention that majoritarian lawmaking has encroached on the claimant's "property."

Let us for now agree on the need in constitutional law for a trans-majoritarian standard of encroachment on property. How and whence to draw the requisite standard? Before us are two competing responses, Epstein's and the Supreme Court's. I want to postpone my account of the Court's approach. Under Epstein's proposal, the baseline for constitutional-legal protection of prop-

Property is nothing but a basis of expectation ... of deriving certain advantages from a thing which we are said to possess [which] can only be the work of law . . . . Before laws were made there was no property; take away laws, and property ceases.

3 The argument, in property-talk, would be that all property titles are already subject from the moment of acquisition to the regulatory servitude of the state-or, in other words, all titles always have conceptually built into them the liability to redefinition by regulatory lawmaking. Accordingly, acts of regulatory lawmaking would register not as transfers of entitlements but rather as the state's exercise of an entitlement that it has held all along.

4 See Richard A. Epstein, Takings, Exclusivity ana Speech: The Legacy of PruneYard v Robins, 64 U Chi L Rev 21, 24-27 (1997). In the words of Justice Antonin Scalia: "[1]f the protection against physical appropriations of private property [is] to be meaningfully enforced, the government's power to redefine the range of interests included in the ownership of property [is] necessarily constrained by constitutional limits." Lucas, 505 US at 1014. It does not follow, though, that the "limits" must take the form of a constitutionally entrenched conception of "property's" core content. Another approach is to focus on changes in law, treating as compensable "takings of property" a state's impositions of losses by alterations of regulatory law that unfairly defeat an owner's "distinct, investment-backed expectations." Id at 1019 n 8, quoting Penn Central Transportation Co $v$ New York City, 438 US 104, 124 (1978). It is hyperbole, therefore, when Epstein proclaims that rejecters of core-content "baselines" for constitutionally protected property never propose alternative "substantive baseline[s]." See Epstein, 64 U Chi L Rev at 23 (cited in note 4). 
erty would be taken directly from the general common law of trespass and nuisance. We can follow Epstein in calling this a "natural" standard because Epstein, for reasons we shall soon notice, decidedly treats the common law as an expression of right reasoning in the service of natural human interests. ${ }^{5}$ The natural standard has roots in a theory of governmental legitimacy attributed by Epstein to Locke, according to which the government can have only the pooled powers that its constituents would have had in a state of nature. ${ }^{6}$ On the present occasion, though, Epstein is less occupied with deep matters of political justification than he is with a more proximately instrumentalist defense of a common law baseline for unconstitutional property encroachment. Such a baseline promises, he says, the kind of rigor and objectivity required for effective judicial restraint of majoritarian excess without undue politicization of the judiciary. Notice, though, that this claim for the rigor and objectivity of the common law standard depends on Epstein's readiness to take a rather strong-armed approach to what he knows lawyers often find a somewhat shapeless, untidy, and refractory corpus juris. Avoiding "rights skepticism," he says, means rationally reconstructing the materials, distilling from them their "brooding omnipresence."'

Epstein's move to rational reconstruction raises, in turn, the question of what authority he can summon for his resulting constitutional-legal prescriptions. Right reason has its hold on American constitutional consciousness, but so have tradition and consent. Epstein understandably wants the support of them all, the historically embedded as well as the more transcendently speculative factors. My suggestion here is that he does not and cannot succeed in having them all. In order to have his way with the takings issue, Epstein would have to persuade the country that he is offering the rightly reasoned answer to this issue, in the teeth of the country's actually prevailing, historical understandings and commitments to the contrary.

\section{IN DEFENSE OF PRUNEYARD}

A. The Public Interest

PruneYard ${ }^{8}$ involves a state law stripping private mall owners of rights to expel political leafleteers, rights that presumably

\footnotetext{
See text accompanying notes 18-19.

- See Epstein, 64 U Chi L Rev at 26-27 (cited in note 4); Richard A. Epstein, Takings: Private Property and the Power of Eminent Domain 12-13 (Harvard 1985).

7 Epstein, 64 U Chi L Rev at 24-25 (cited in note 4) (citation omitted).

s PruneYard Shopping Center v Robins, 447 US 74 (1980).
} 
would otherwise have been theirs. Epstein sharply questions whether such a law serves any constitutionally valid public "use" or interest. True, he concedes that the PruneYard law passes the test of public use as currently construed, and he accordingly confines his official legal attack to the law's failure to compensate for taken property. ${ }^{9}$ I cannot skirt the issue in my response, however. My rejoinder to the compensation claim will be that the state's action in this case merely offsets a harm to an important public interest that the mall operation would otherwise be causing. It will, therefore, be incumbent on me to rebut Epstein's diametrically opposed denial of any legitimate public interest served by the law.

First, however, we must clear away a side issue. As Epstein accurately reports, my defense of PruneYard depends on attributing certain values, objectives, and policies to California

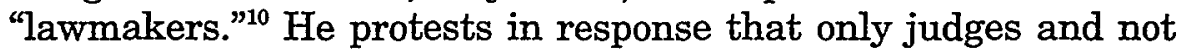
popular bodies brought forth the property-restrictive doctrine that he criticizes. ${ }^{11}$ But that is not precisely true because the California Supreme Court based its ruling on a legislative text: Article I, Section 2 of the California Constitution. ${ }^{12}$ But let us grant-as I imagine Epstein would insist-that the court's interpretation of the constitutional text was an activist one; or let us suppose that the ruling was purely common law based. In the eyes of the United States Supreme Court this ruling would still have had the status of a legal-policy declaration by duly authorized legal-policy declarers of the state, namely, its common law or interpretively activist judiciary. ${ }^{13}$ Because such a judiciary is incontestably "republican," ${ }^{\text {"14 }}$ California's making it a part of state

- See Epstein, 64 U Chi L Rev at 35 (cited in note 4).

${ }^{10}$ Id at 43-44.

"See id.

${ }_{12}$ "Every person may freely speak ... his or her sentiments on all subjects .... A law may not restrain or abridge liberty of speech." Robins $v$ PruneYard Shopping Center, 23 Cal 3d 899, 592 P2d 341, 346 (1979), quoting Cal Const, Art I, § 2.

${ }^{13}$ In referring to the court's law-declaring function as one of policy declaration, I do not mean that the court steers by "policy" as opposed to "principle" in the sense of those terms as introduced by Ronald Dworkin. See, for example, Ronald Dworkin, Taking Rights Seriously 82-84 (Harvard 1977). I am happy to assume that when courts declare policy, they do so as required, in their best judgment, by legal principles of right and wrong that they find in a "moral reading" of the law. See, for example, Ronald Dworkin, Freedom's Law 1-38 (Harvard 1996).

" See US Const, Art IV, $\$ 4$ ("The United States shall guarantee to every State in this Union a Republican form of government."). One cannot maintain with a straight face (and least of all can Professor Epstein) that a strong common lawmaking judiciary, or one that gives a "moral reading" to constitutional clauses, is unrepublican by American constitutional standards-at least as long as the court's actions are subject to override by popularly based lawmaking, a condition that is notoriously satisfied in California. 
government is no concern of the Supreme Court's. Nor is it any of ours here. Granted, the state court's PruneYard decision may have been both unanticipated by California's constitutional framers and surprising to the state's current voters. Howevercontrary to Epstein's suggestion-my PruneYard defense rests nothing on contemporaneous majority approval of the aims and policies it attributes to California lawmakers.

My defense does envision California's authorized legal-policy declarers acting purposively on behalf of a specific public interest or "use"-that consisting in provision of what we can call a civic common. A civic common is a site that not only accommodates cerebral exchanges of ideas but, at the same time, generates a supportive good that we may call civic sociability, an aspect of what others have recently been calling "social capital."15 This good, as I envision California policymakers conceiving it, depends on there being actual places where people meet each other over matters of common concern in the course of daily life. Suppose, now, that authorities in some state use eminent domain powers to take from each mall owner in the state the public easement required to sustain a civic common on each mall site. Epstein questions whether such a taking would be for a constitutionally proper public use. His doubt seems to fly in the face of a boilerplate proposition of American common and constitutional law: the "time out of mind" tradition of impressment-by-operation-oflaw of a civic-commoning easement on governmentally owned streets, plazas, and parks. ${ }^{16}$ Given that doctrine, which Epstein does not question, ${ }^{17}$ how can he possibly doubt that provision by government action of public-commoning spaces, within privately owned but otherwise functionally similar sites, is a constitutionally proper public use?

He doubts it, he says, because he doubts that a public use occurs when someone enters your land "for partisan political purposes."18 That seems rather obviously to miscast the issue, which would appear to be not the "publicness" of any particular entry but the "publicness" of a general politicking privilege available to everyone. Epstein nevertheless persists with the idea that there is something deeply constitutionally amiss here, respecting

\footnotetext{
"See, for example, Robert Putnam, Bowling Alone: America's Declining Social Capital, $6 \mathrm{~J}$ Democracy 65, 67 (Jan 1995) (''S]ocial capital' refers to features of social organization such as networks, norms, and social trust that facilitate coordination and cooperation for mutual benefit.").

${ }^{15}$ See Hague v Committee for Industrial Organization, 307 US 496, 515 (1939) (Roberts opinion).

${ }^{17}$ See Epstein, 64 U Chi L Rev at 44 (cited in note 4).

${ }^{14}$ Id at 34.
} 
equality and free speech. There is, he says, an untoward "viewpoint" discrimination when government devotes its powers and funds to impressment of a civic common on otherwise private land, for it seems that "some speakers (usually those who are left-wing and anti establishment types) will be far more likely to commandeer these resources than will other speakers." ${ }^{\text {"19 }}$ What "discrimination" does he mean? Does he mean the relative advantage accruing to would-be speakers who actually want to make active use of the state-impressed common, by comparison with those who do not? ${ }^{20}$ Given a public-wide, content-neutral, state-supported legal privilege to politick at the mall, Epstein would then be saying that some will have use for it and some will not, and those who do not (perhaps because they are able to obtain access to preferred channels of influence) are the victims of a discriminatory subsidy. But of course the same "discrimination" applies without a hitch to the traditional civic-common servitude on governmentally owned streets and squares. So if it is this discrimination that Epstein means, it would be hard to square his view with the American constitutional and common law tradition of state support-indeed, mandatory state support-for civiccommoning.

What other "discriminations" are in sight? The state is plainly preferring the special interests that some people have in civic-commoning as a channel of political communication, over the no less special interests held by profit-motivated mall owners and by those who seek to evade "political controversy."21 This preference is not, however, a discrimination between one person's speech and another's; it is not remotely a case of "restrict[ing] the speech of some elements of our society in order to enhance the relative voice of others . . .."22 Calling it on the constitutional carpet seems just another form of rejection of our law's seemingly

19 Id at 52.

"Note that, so far as the "public use" issue is concerned, there is no compelled special contribution from any landowner, because the assumption is one of a duly compensated express taking by eminent domain.

${ }^{21}$ Epstein, 64 U Chi L Rev at 44 (cited in note 4). In suggesting that the mall owners' and (as he supposes) shoppers' preference for freedom from politicking defeats the public use claim, Epstein seemingly equates "public use" with Pareto-superiority: absence of self-assessed detriment to anyone from a state-imposed property redeployment. See id at 34 (That "neither the owners nor the shoppers receives a benefit" falsifies the premise of "benefit to all."). That suggested equation seems indefensible. Condemnation of the PruneYard for public road construction would be incontestably constitutional, no matter how strongly, sincerely, and understandably the mall's owners, lessees, and customers would have preferred otherwise, even after all the constitutionally requisite compensation had been paid.

${ }^{22}$ Buckley v Valeo, 424 US 1, 48-49 (1976). 
settled acceptance of the constitutional merit of civic-commoning as a true public value. States, in other words, are free to prefer the public values of their choice over interests in proprietary exclusivity-always, of course, subject to non-discrimination duties and to the First, Third, and Fourth Amendments, and sometimes to a compensation requirement. But then what about the exaction of "subsidies" from mall owners to support other people's political speech, ${ }^{23}$ or the special burdening of mall owners as opposed to other possible providers (including the taxpayers) of sites for civic-commoning? These questions take us beyond the issue of public use to that of the mall owners' rights to compensation for their burdens. ${ }^{24}$

\section{B. The Right to Compensation}

First, several arguendo stipulations in Epstein's favor: (1) a measurable detriment flows to mall owners (and others for whom they proxy-some lessees, some shoppers) from the state's impressment of civic-commoning easements on mall sites, ${ }^{25}$ (2) owners do not waive their rights against non-shopper interlopers by opening their gates to shoppers; ${ }^{26}(3)$ as a prima facie rule, the Constitution requires states to compensate for losses occasioned by regulatory lawmaking that restricts landowners' presumptive freedom to exclude others at will. ${ }^{27}$ Epstein's proposed common law standard of constitutional property protection, however, inevitably carries with it a qualification of this prima facie rule: the rule cannot then apply to restrictions fairly designed to rectify deployments of affected land that lawmakers-judicial or parliamentary-could aptly classify as nuisances. ${ }^{28}$

In the vocabulary offered by Carol Rose, civic commons are comedic, not tragic. ${ }^{29}$ Their characteristic vulnerability is not to overuse but to underuse; for them, "the more the merrier."

\footnotetext{
${ }^{23}$ See Epstein, 64 U Chi L Rev at 52 (cited in note 4).

${ }^{24}$ If, as I contend below, a public easement at the mall for civic-commoning compensates the public for losses of social capital that are fairly attributable to mall development, then one cannot complain of either a subsidy or an unfair burden.

${ }^{2}$ See Epstein, 64 U Chi L Rev at $48-49$ (cited in note 4).

$\approx$ See id at $36-40$.

${ }^{n}$ See id at 22.

* A point about the common law category of public nuisance that Epstein does not notice in his discussion is that the common law traditionally contained an invitation to parliamentary bodies, along with judicial ones, to play their parts in defining offenses against the public weal. See generally John A. Humbach, Evolving Thresholds of Nuisance and the Takings Clause, 18 Colum J Envir L 1 (1993).

${ }^{*}$ Carol Rose, The Comedy of the Commons: Custom, Commerce, and Inherently Public Property, 53 U Chi L Rev 711 (1986).

$\Rightarrow$ See id at 768.
} 
Lawmakers may conclude with good reason that processes of suburban and exurban development have been a direct contributing cause of the socially costly degradation suffered by urbancenter spaces. Furthermore, these destructive exurbanizing processes (which is not to say that the processes have not also been constructive) have been fueled by the private provision of shopping malls, which have contributed to the destruction of urbancenter civic commons and their attendant social capital. Why would not this platitudinous observation give the lawmakers just cause to require the mall developers, or their successors in title, to contribute in apt fashion to replacing the social values their profit-seeking pursuits have helped to destroy? ${ }^{31}$ Where, in such circumstances, is the justice of making the public pay off the developers for costs of replacing what the developers' self-serving actions have helped to ruin? Why, indeed, should judges or other lawmakers not be free to identify as a public nuisance actions contributing to the degradation of pre-existing, urban-center social capital?

A common law nuisance claim contains propositions both about a legally established public interest and about a legally culpable manner of harming that interest. If the first proposition is unsustainable, the claim fails for want of a legally cognizable harm. If the second proposition is unsustainable, the claim fails by reason of privilege: a legally cognizable harm may have been proximately caused by someone creating a shopping mall but that act is nevertheless not a legal "injury" or wrong-the case is then one of damnum absque injuria. Notwithstanding Epstein's suggestion to the contrary, impairment of a civic common should clearly register as damnum in our jurisprudence, a harm in the eyes of the law. ${ }^{32}$ The question remains whether producing such a harm by the seemingly innocent act of creating a mall is injuria and legally rectifiable. On Epstein's view, an answer unsullied by politics must be discoverable in a rational reconstruction of nuisance law. What, then, is that answer?

Epstein says the case does not strike him as falling easily into an itemized list of public nuisance case types provided by the Dean of Torts. ${ }^{33}$ But of course a gestalt judgment here, insofar as

${ }^{31}$ For a case of judicial-law declarers apparently reasoning in just this fashion, see New Jersey Coalition Against War in the Middle East v J.M.B. Realty Corp, 138 NJ 326, 650 A2d 757 (1994), cert denied, Short Hills Associates $v$ New Jersey Coalition Against War in the Middle East, 116 S Ct 62 (1995).

${ }^{32}$ See Section II.A.

${ }^{3}$ See Epstein, 64 U Chi L Rev at 41-43 (cited in note 4). 
that is what Epstein may intend, ${ }^{34}$ would not be very insulable against the partisan views of the applier. There is the further problem, too, that the Dean's list may be somewhat unsystematic. For example, it includes "obstructing . . . a stream," but omits mention of the diversion of waters from a stream that impairs socially valued downstream uses. ${ }^{35}$ Prosser's omission is a convenient one for Epstein, because once the diversion of waters case is on the table, one cannot easily deny either that it is standard nuisance material ${ }^{36}$ or that an analogy between it and our case is detectable. (As between the economically productive or otherwise non-wanton diversion of water from a stream and the diversion of civic life from urban centers, has the former any more than the latter the character of a "physical . . . invasion" or "crime?"38)

What about the common law privilege of competition? It is certainly true that deeply entrenched in our law is a privilege to compete trade away from other would-be sellers by offering better mousetraps. Here, however, the state complains of a harm consisting of a loss of social value output from a site that it owns, which is quite a different sort of harm from the loss of sales revenues to product-line competitors. In that respect, our case is not about a competitive injury; ${ }^{39}$ it is about an environmental injury. The injury accrues in the form of diminished attendance at "comedic" public sites, occasioned by acts of others trying to do what will foreseeably and directly cause this result and standing to benefit in proportion to their success. Our case at least bears an arguable analogy to one example well within the ambit of "nuisance" classification: non-malicious but objectively intentional pollution of a public natural resource by the defendant's self-benefiting, but otherwise lawful and commendable, act. But perhaps the fairest characterization of our case is that it is a confusing mixture of both competitive and environmental injury. Perhaps that makes it a hard case at common law and thus one that's legitimately decidable either way. ${ }^{40}$ If so, then under a

\footnotetext{
34 I deal below with rational reconstruction or distillation of a controlling principle.

${ }^{35}$ W. Page Keeton, et al, Prosser \& Keeton on the Law of Torts $\S 90$ at 643-45 (West 5th ed 1984 \& Supp 1988).

Nothing turns for present purposes on the common law's habit of subsuming this case under the specific heading of "riparian rights" rather than residual, catch-all "nuisance."

5 Epstein, 64 U Chi L Rev at 42 (cited in note 4).

an Id.

${ }^{3}$ See id at $42-43$.

4:" "Legitimately decidable either way" does not mean that the judicial decider is free to pick her personally preferred result, as opposed to reporting her best judgment as to the best legal answer. It means that competent and sincere judicial deciders will fairly
} 
common law baseline for constitutional "property," the mall owner seeking compensation is whistling in the wind, because the risk of having hard cases decided against you is surely a part of what you buy into in a common law system. ${ }^{41}$

Have I, perhaps, made the case "hard" when it really is not, by overplaying the (notorious) shapelessness of the nuisance corpus juris? Have I, in other words, overlooked the crucial reliance of Epstein's argument on rational reconstruction? I have had rational reconstruction very much in mind, but I believe that a resort to it can do no better for Epstein than take him from the frying pan to the fire, from indeterminacy to politicization.

There can be no fairer test, I assume, than Epstein's own suggested distillation of nuisance law's "brooding omnipresence": "[M] aximize the joint value of all properties subject to law, subject to the side constraint of equality of rights between neighbors." ${ }^{\text {2 }}$ Given (a) our law's glaringly strong positive valuation of civic-commoning as social capital, and (b) the commonplace observation of a causal link between suburban shopping mall development and the depletion of this kind of social capital elsewhere, what is outlandish about a lawmaker's judgment that joint value is maximized by a rule requiring capital replacement by mall developers? ${ }^{43}$ After all, if the mall does not strike expectant investors as a winning proposition after covering the costs of replacing any social capital destroyed by its introduction, then maybe it is a net socially costly project that ought not to be built. Granted, there are several possible counter-considerations: (1) apportionment to malls in general or to any given mall of a substantial share of responsibility for urban-center social capital destruction could be mistaken; or (2) the malls' typical replacement costs could significantly exceed both (a) the typical values of the social capital losses attributable to mall building, and (b) the typical values of the resulting new civic commons. But guesswork about such matters is endemic in common law decisionmaking. It would be hard to dismiss as incompetent or insincere a lawmaker's estimate of the probable efficiency of the PruneYard law-unless one simply could not accept our law's clear designation of civic-commoning as a weighty social good. Yet that is ex-

and reasonably disagree over what that answer is. See Dworkin, Taking Rights Seriously at 81 (cited in note 13).

"On the question of judicial decisions as compensable takings, see generally Barton H. Thompson, Jr., Judicial Takings, 76 Va L Rev 1449 (1990).

${ }^{12}$ Epstein, 64 U Chi L Rev at 28 (cited in note 4).

43 If the answer to that question is "nothing," then there is no further basis for complaining of deviation from equality of rights (assuming that mall development by everyone carries the same exposure). 
actly what the United States Supreme Court would have to do in order to find a compensable event here if the common law, rationally reconstructed as Epstein would do it, is to provide the takings baseline. In condemning California's rule that the impressment of civic-commoning privileges on shopping malls goes uncompensated, the Court would have to say that this rule could not reasonably or fairly be judged to maximize the joint value of the properties. But saying that would disclose on the Court's part a dismissiveness toward the civic-commoning value that, given our legal tradition, could only be classed as biased and partisan. Such a pronouncement by the Court would be indelibly politicized.

\section{FROM PROPERTINESS TO FAIRNESS}

Is there a better way? Epstein would have us look outside the Constitution for a standard of constitutional property protection, to a natural legal reason distilled from common law/private law materials. How about looking inside the Constitution, to the Takings Clause itself, for what we can call a political as opposed to a natural standard-a standard specifically geared to the public law work of differentiating between constitutionally permissible and impermissible government actions, or, in other words, to policing the engagement between property and democracy? By a "political" standard I do not mean one that is in any special degree a dictate of majority will as opposed to judicial judgment. I mean one that reflects judicial elucidation (with specific reference to property) of a complex political ideal, that of constitutional democracy. For example, the purpose of the Takings Clause is "to bar Government from forcing some people alone to bear public burdens which, in all fairness and justice, should be borne by the public as a whole, ${ }^{34}$ and the requisite fairmess determination "necessarily requires a weighing of private and public interests. ${ }^{245}$ According to these declarations, protection does not inhere in any naturalistic notion of property as such. Rather, it falls out of a judgment of political fairness: if, in the general context of American constitutionalism, it is unfair for politics to impose on property in the challenged way without compensation, then property has been taken, and vice-versa. ${ }^{46}$ Judicial partisan-

"Armstrong $v$ United States, 364 US 40, 49 (1960) (Harlan dissenting).

* Agins $v$ City of Tiburon, 447 US 255, 260-61 (1980).

"Compare William Michael Treanor, The Original Understanding of the Takings Clause and the Political Process, 95 Colum I Rev 782, 819-25, 880-82 (1995) (contending, on both originalist and non-originalist grounds, that the application of the Takings Clause turns on a political fairness judgment but denying that the Supreme Court's re- 
ship remains, of course, a concern, but the "political" or fairness approach may fare better in this respect than any resort to a common law baseline. Better, one might say, to have a constitutional court tackle openly and directly the political fairness concerns that uncompensated regulation sometimes raises, than to let the judges veto regulatory laws in the name of unprovable and contestable common law essences.

Is this on my part just a wistful reversion to the halcyon social democratic days of the Warren and Burger Courts? Happily, the Reagan and Bush Court also seems to have remembered the poisonous effects of judicial pretensions to discover by reason a natural constitutional law of property and, despite signs of temptation, ${ }^{47}$ to have mainly steered clear. The decisive case is Lucas, where Justice Scalia referred for an answer not to reason or nature but to "tradition[ ]," "compact," and "culture." "[O]ur 'takings' jurisprudence," he wrote,

has traditionally been guided by the understandings of our citizens regarding the content of, and the State's power over, the "bundle of rights" that they acquire when they obtain title to property. It seems to us that the property owner necessarily expects the uses of his property to be restricted, from time to time, by various measures newly enacted by the State in legitimate exercise of its police powers; "[a]s long recognized, some values are enjoyed under an implied limitation and must yield to the police power."

[W]e think the notion ... that title to land is . . . subject to the "implied limitation" that the state may subsequently eliminate all economically valuable use is inconsistent with the historical compact recorded in the Takings Clause that has become part of our constitutional culture. ${ }^{48}$

I do not find this rhetoric perfect by any means. To my mind, it goes too far in the direction of displacing judicial accountability for a fairness judgment onto a "tradition" that I believe no likelier to be objectively decisive in this field, or impervious to parti-

cent adjudications adequately reflect this understanding).

${ }^{47}$ See Frank I. Michelman, Property, Federalism, and Jurisprudence: A Comment on Lucas and Judicial Conservatism, 35 Wm \& Mary L Rev 301, 320-21 (1993) (uncertainly spotting a trace of natural lawyering in the Court's appeal to the idea of "essential uses" of landed property).

${ }^{4}$ Lucas v South Carolina Coastal Council, 505 US 1003, 1027-28 (1992), quoting Pennsylvania Coal Co v Mahon, 260 US 393, 413 (1922). 
sanship, than is legal naturalism or a common law baseline. ${ }^{49}$ But the central idea is right: thoughts of compensation are, by the prevalent understanding of Americans regarding property's interface with democracy, simply out of place in most instances, if not quite all, of regulatory restrictions of land use. American constitutional democracy's disposition from the beginning has been to treat the bulk of these events as belonging to the normal give and take of a progressive, dynamic, democratic society. ${ }^{50}$ Regulation stands, in our public law, as an ordinary part of the background of risk and opportunity against which we all take our chances in our roles as investors in property. 
, 